\title{
Edukacja zdalna. Adaptacja procesu dydaktycznego do potrzeb osób z niepełnosprawnościami
}

Justyna Migacz

Niezależna badaczka 


\title{
Streszczenie
}

W artykule przedstawiono informacje dotyczące adaptacji procesu studiowania do potrzeb wybranych grup osób z niepełnosprawnościami. Artykuł skupia się na dostosowaniu edukacji zdalnej. Zdefiniowano pojęcie adaptacji procesu kształcenia. Zaprezentowano sugestie dotyczące komunikacji z osobami z niepełnosprawnościami. Przedstawiono adaptacje edukacji zdalnej w podziale na grupy osób z niepełnosprawnościami. Prezentowane w artykule informacje przedstawiono na podstawie literatury przedmiotu oraz obserwacji i doświadczenia autorki. W artykule zaprezentowano wiedzę praktyczną. Ze względu na posiadane przez autorkę doświadczenie znaczną część artykułu poświęcono omówieniu dostosowania edukacji zdalnej do potrzeb osób z niepełnosprawnością narządu wzroku. W artykule zwrócono uwagę na różnice pomiędzy edukacją zdalną i konwencjonalną. Wskazano na różnice $\mathrm{w}$ adaptacji procesu kształcenia osób niepełnosprawnych wynikające z zastosowania edukacji zdalnej.

\section{Słowa kluczowe}

adaptacja edukacji online, niepełnosprawność, proces kształcenia online, studia wyższe, włączenie.

\section{Online education. Adaptation of the teaching process to the needs of people with disabilities}

\begin{abstract}
The article presents information on the adaptation of the study process to the needs of selected groups of people with disabilities. The article focuses on adapting remote education. The concept of adaptation of the education process was defined. Suggestions for communication with people with disabilities were presented. Adaptations of remote education divided into groups of people with disabilities were presented. The information presented in the article is based on the literature on the subject as well as the author's observations and experience. The article contains practical knowledge. Due to the experience of the author, a significant part of the article is devoted to discussing the adaptation of remote education to the needs of people with visual disabilities. The article highlights the differences between distance and conventional education. Differences in the adaptation of the education process of people with disabilities resulting from the use of remote education were indicated.
\end{abstract}

\section{Keywords}

adaptation of online, education disability, higher education, inclusion, online education process. 
Celem mojego artykułu jest przedstawienie adaptacji procesu dydaktycznego do potrzeb wybranych grup osób z niepełnosprawnościami w szkole wyższej. Sądzę jednak, że zawarte w nim wskazówki będą użyteczne także w przypadku pozostałych etapów kształcenia. Ponadto treść artykułu, chociaż adresowana przede wszystkim do nauczycieli akademickich, może okazać się przydatna dla innych pracowników uczelni oraz pełnosprawnych studentów.

Zapoznając się z treścią dokumentów dotyczących adaptacji procesu studiowania, można zauważyć, że część informacji ma charakter ogólny. Oznacza to, że niektóre adaptacje pojawiające się w materiałach dotyczących dostosowania spotkania online mają swoje zastosowanie także w przypadku edukacji konwencjonalnej (pojęcia tego używam w odniesieniu do edukacji odbywającej się na terenie uczelni).

Adaptacje procesu studiowania do potrzeb osób z niepełnosprawnościami można podzielić na:

1) ogólne - czyli niezależne od trybu odbywania zajęć;

2) dotyczące tylko edukacji konwencjonalnej;

3) dotyczące tylko edukacji zdalnej.

Podział adaptacji na wymienione powyżej trzy kategorie wynika $\mathrm{z}$ analizy danych zastanych oraz własnych obserwacji. W artykule skupię się na przedstawieniu trzeciej kategorii adaptacji - adaptacji dotyczących edukacji zdalnej. Jednak z uwagi na to, że edukacji zdalnej mogą towarzyszyć także kontakty bezpośrednie nauczyciela akademickiego i studenta, omówienie adaptacji spotkań online do potrzeb osób wynikających z konkretnych niepełnosprawności poprzedzę ogólnymi uwagami dotyczącymi studiowania osób niepełnosprawnych. Podam kilka informacji odnoszących się do komunikacji pomiędzy studentem niepełnosprawnym a nauczycielem akademickim (które mają jednocześnie zastosowanie w szerszym kontekście, jeśli dotyczą komunikacji pomiędzy osobą niepełnosprawną a osobą pełnosprawną). Część z tych informacji odnosić się będzie do edukacji w ujęciu ogólnym, część będzie miała zastosowanie tylko w przypadku kontaktów bezpośrednich.

Następnie przedstawię adaptacje zajęć zdalnych w podziale na rodzaje niepełnosprawności, których one dotyczą. Omówię dostosowania spotkań online do potrzeb osób z niepełnosprawnością:

1) narządu wzroku;

2) narządu słuchu;

3) narządu mowy;

4) narządu ruchu.

Prezentowane informacje opieram na literaturze przedmiotu, własnych obserwacjach i doświadczeniu.

Jestem absolwentką studiów dziennych. Od marca do czerwca 2020 r. studiowałam zdalnie. Dlatego posiadam doświadczenie związane zarówno z edukacją konwencjonalną, jak i zdalną. Jestem ponadto osobą niepełnosprawną (słabowidzącą). W związku z tym 
znaczną część dostosowań procesu kształcenia do potrzeb osób z dysfunkcją wzroku przedstawiam z perspektywy i doświadczenia osoby z nich korzystającej. Jest to zatem wiedza praktyczna. Zamieszczam informacje na temat rozwiązań, które w moim przypadku były skuteczne oraz problemów, które się pojawily lub których występowanie zaobserwowałam w przypadku innych studentów z niepełnosprawnością wzroku. Nie oznacza to jednak, że przedstawione uwagi i sugestie mają charakter uniwersalny. Coś, co dla jednej osoby może stanowić problem, barierę, dla innej, nawet ze znacznie zbliżoną dysfunkcją organizmu, może być neutralne. Nie roszczę sobie prawa wypowiadania się $\mathrm{w}$ imieniu studentów z niepełnosprawnością wzroku. Zwracam jedynie uwagę na kwestie, które dostrzegam, a które nie zostały poruszone lub zostały poruszone w niewystarczającym stopniu w publikacjach dotyczących dostosowania procesu kształcenia do potrzeb osób z niepełnosprawnością wzroku.

\section{ADAPTACJE PROCESU STUDIOWANIA. INFORMACJE OGÓLNE}

„Adaptacje procesu kształcenia to zmiany w toku studiów stwarzające możliwość wywiązywania się z obowiązków akademickich, które uwzględniają sytuację zdrowotną oraz specyfikę wymagań merytorycznych danego kierunku" (Dostosowanie procesu kształcenia, b.d.). Celem adaptacji jest umożliwienie studiowania osobom niepełnosprawnym. Adaptacje minimalizują wpływ niepełnosprawności na funkcjonowanie studenta na uczelni. Ich celem jest pomaganie w osiągnięciu przez studenta niepełnosprawnego ( $\mathrm{w}$ takim stopniu, $\mathrm{w}$ jakim jest to możliwe $\mathrm{z}$ uwzględnieniem jego niepełnosprawności) niezależności na studiach (Dostosowanie procesu kształcenia, b.d.). Adaptacje obejmują dostosowanie zajęć, materiałów oraz zaliczeń i egzaminów.

Ponieważ adaptacje to zmiany mające na celu umożliwienie studentowi niepełnosprawnemu wywiązywanie się z obowiązków studenta z uwzględnieniem wymagań merytorycznych, nie chodzi o zmianę wymagań czy stosowanie taryfy ulgowej. Przed studentami niepełnosprawnymi "należy stawiać takie same wymagania jak przed innymi studentami, ponieważ zamierzają oni zdobyć wyższe wykształcenie, a to uczelnia odpowiada za uzyskany przez nich dyplom" (Szczepankowski, b.d.). Stawianie takich samych wymagań nie stoi w sprzeczności z odmiennym niż w przypadku innych studentów zdobywaniem wiedzy (np. korzystaniem z zaadaptowanych materiałów), ani odmiennym niż w przypadku pozostałych studentów weryfikowaniem zdobytej wiedzy (np. zmianą formy egzaminu na ustny). Student niepełnosprawny kończący studia powinien posiadać taką samą wiedzę i takie same umiejętności jak pozostali pełnosprawni absolwenci. Z moich obserwacji wynika, że stawianie przed studentem niepełnosprawnym mniejszych wymagań, niż w stosunku do pozostałych studentów, nie jest działaniem na jego korzyść. Działanie takie może wpływać m.in. na:

1) obniżenie motywacji studenta niepełnosprawnego;

2) obniżenie poczucia własnej wartości studenta niepełnosprawnego;

3) ograniczenie posiadanej przez studenta niepełnosprawnego wiedzy i nabytych umiejętności (co może skutkować zmniejszeniem konkurencyjności na rynku pracy); 
4) postawy innych studentów wobec studenta niepełnosprawnego i relacje pomiędzy studentem niepełnosprawnym a innymi studentami (co może mieć odzwierciedlenie $\mathrm{w}$ chęci lub niechęci do pracy w grupie ze studentem niepełnosprawnym);

5) powstawanie wyuczonej bezradności.

W kontaktach ze studentem niepełnosprawnym należy zachowywać się w sposób naturalny, nie zmieniać swojej wypowiedzi, tak by odnosiła się do niepełnosprawności. Nie jest nietaktem używanie w stosunku do lub w obecności osób niewidomych albo słabowidzących określeń odnoszących się do odbioru za pomocą zmysłu wzroku (analogicznie w przypadku osób niesłyszących lub słabosłyszących - słuchu). Filmy się ogląda, książki i artykuły czyta, plików audio słucha. Nie ma potrzeby, a wręcz nie należy, zastępować powszechnie używanych słów innymi. To, czy student przeczyta artykuł samodzielnie, czy wysłucha go w formie przetworzonej przez syntezator mowy, nie ma znaczenia dla celu, jakim jest zapoznanie się z jego treścią. Osoby niepełnosprawne same używają określeń odnoszących się do czynności, których nie wykonują, tak samo jak osoby pełnosprawne - np. niewidomi mówią, że czytają książkę, podczas gdy w rzeczywistości słuchają audiobooka lub tekstu przy użyciu syntezatora mowy. Nie powinno się również zastępować zwrotów grzecznościowych, np. „do widzenia” na „do usłyszenia” w kontakcie z osobą z niepełnosprawnością wzroku, czy też na odwrót - w przypadku kontaktu z osobą z niepełnosprawnością słuchu. Taki sposób wypowiadania się jest sztuczny.

Jeżeli student korzysta z pomocy osoby trzeciej, należy zwracać się bezpośrednio do studenta. Podczas zajęć, w których bierze udział tłumacz języka migowego, należy zwracać się do wszystkich studentów, w tym osoby niesłyszącej (Szczepankowski, b.d.). Rozmawiając ze studentem korzystającym z pomocy tłumacza języka migowego, należy zwracać się bezpośrednio do studenta, a nie do tłumacza. Nie powinno się używać zwrotów pośredniczących między tłumaczem a studentem takich, jak np.: „proszę zapytać” (Wsparcie edukacyjne studentów z niepełnosprawnością słuchową, b.d.). Analogicznie, $\mathrm{w}$ przypadku studentów $\mathrm{z}$ innymi niepełnosprawnościami w trakcie rozmowy należy zwracać się do studenta, a nie do osoby mu towarzyszącej (przewodnika osoby z dysfunkcją wzroku czy asystenta osoby z niepełnosprawnością narządu ruchu). Nie oznacza to braku szacunku wobec osoby towarzyszącej studentowi. Osoba towarzysząca pomaga studentowi w komunikacji (tłumacz języka migowego), przemieszczaniu się (przewodnik osoby z dysfunkcją wzroku), przemieszczaniu się i innych czynnościach (asystent osoby z niepełnosprawnością narządu ruchu), nie jest ona jednak studentem, a co za tym idzie, podmiotem komunikacji.

Kontynuując temat komunikacji, warto jeszcze wspomnieć o wpływie, jaki ma na nią niepełnosprawność narządu wzroku. Zwracając się do osoby z niepełnosprawnością wzrokową (np. zadając jej w trakcie zajęć pytanie), należy słownie sprecyzować adresata wypowiedzi. Osoby niewidome, a także część osób słabowidzących, nie zareagują ani na spojrzenie, ani na wskazanie palcem (Zadrożny, b.d.). Ma to zastosowanie we wszystkich sytuacjach (nie tylko w trakcie zajęć), w których jakaś osoba chce nawiązać komunikację z osobą niewidomą lub słabowidzącą. Słowne precyzowanie adresata wypowiedzi umożliwia nawiązanie komunikacji. W przypadku studentów słabowidzących należy też 
wziąć pod uwagę, że to, iż dana osoba patrzy się na wykładowcę, nie musi oznaczać, że widzi ona, iż ów wykładowca również się na nią patrzy. Może dojść do sytuacji, w której kontakt wzrokowy jest pozorny. Student patrzy się na osobę prowadzącą zajęcia, osoba prowadząca zajęcia patrzy się na studenta i może odnieść mylne wrażenie, że komunikuje się z nim przy użyciu spojrzenia. Spotkałam się z tym, że osoba słabowidząca wolała unikać możliwości wystąpienia takiej sytuacji i celowo nie patrzyła się na osobę prowadzącą zajęcia” (Migacz, 2020, s. 21-22).

To, że dana osoba nie jest niewidoma, lecz słabowidząca, nie musi oznaczać, że rozpoznaje ona inne osoby z twarzy. Piszę o tym w tym miejscu, gdyż niezależnie od formy zajęć osoba prowadząca zajęcia może niewłaściwie zinterpretować zachowanie studenta w pewnych sytuacjach. Na przykład osoba słabowidząca może nie ukłonić się jako pierwsza, ponieważ nie rozpozna z twarzy drugiej osoby, więc nie jest to przejaw braku kultury. Osoby niewidome i niektóre słabowidzące mogą rozpoznać rozmówcę po głosie. Celowo używam słowa „mogą”. Nie jest to bowiem pewne. Brzmienie głosu pewnych osób jest trudne do zapamiętania, a tym samym rozróżnienia od innych. Im dłużej, częściej słyszy się daną osobę, tym łatwiej rozpoznać jej głos. Oznacza to, że osoba z dysfunkcją narządu wzroku może nie rozpoznać po głosie osoby, z którą miała np. tylko jedne zajęcia. Głos tej samej osoby może też inaczej brzmieć w trakcie spotkania online, a inaczej w kontakcie bezpośrednim.

Niezależnie od rodzaju niepełnosprawności i formy zajęć (zajęcia konwencjonalne czy zajęcia zdalne) jedną z sugerowanych adaptacji jest nagrywanie treści zajęć (zarówno w formie audio, jak i video). Na uwagę zasługuje fakt, że prawo do rejestracji zajęć ma każdy student (niezależnie od tego, czy jest osobą niepełnosprawną, czy też nie). Zgodnie z ustawą o prawie autorskim i prawach pokrewnych każdy uczestnik zajęć ma prawo do ich nagrywania. Nie może jednak rozpowszechniać nagranych materiałów z wyjątkiem rozpowszechniania ich $\mathrm{w}$ gronie najbliższych osób (art. 23 i art. 81, Ustawa z dnia 4 lutego $1994 \mathrm{r}$ o prawie autorskim i prawach pokrewnych).

Informacje przekazywane przez jednostki organizacyjne uczelni do spraw osób niepełnosprawnych, informacje pochodzące z literatury przedmiotu, a także informacje zawarte w tym artykule, będą szczególnie użyteczne w przypadku, gdy student nie jest w stanie dokładnie określić swoich potrzeb, ponieważ nie korzystał wcześniej z jakiegoś rozwiązania, mógł nawet nie być świadomy, że taka możliwość istnieje.

Niezależnie jednak od formy udzielanej pomocy kluczowe jest, by była ona dopasowana do potrzeb konkretnej osoby. Najlepszym źródłem informacji o problemach i potrzebach wynikających z niepełnosprawności oraz o formie i zakresie pomocy, jakiej potrzebuje dana osoba, by móc w pełni uczestniczyć w danym kursie oraz ukończyć go z sukcesem (zdaniem egzaminu, zaliczeniem przedmiotu), jest student niepełnosprawny. Dlatego zaleca się, by pytać studenta o jego potrzeby. „Należy dyskretnie zapytać studenta, jak dużo widzi (...) oraz jaka pomoc będzie mu potrzebna (Zadrożny, b.d.). Należy pamiętać, by nie narzucać się z pomocą, nie pchać wózka bez zgody jego użytkownika, gdyż może to naruszać jego przestrzeń osobistą. W sytuacji, gdy wydaje nam się, że nasza pomoc może być takiej osobie potrzebna, kluczowe jest zapytanie jej o to" (Wsparcie edukacyjne studentów z niepełnosprawnością ruchową, b.d.). 
Nie należy wyręczać osoby niepełnosprawnej. Najlepiej zapytać, czy osoba ta potrzebuje pomocy, czy chce, żebyśmy jej udzielili, a jeśli tak, to jakiej pomocy potrzebuje. Na przykład, jeżeli osoba z dysfunkcją wzroku szuka jakiegoś przedmiotu, można zaproponować jej pomoc, ale dopiero wówczas, gdy widzi się, że nie może ona go znaleźć.

Nie należy bez pytania pomagać w przemieszczaniu się osobie z dysfunkcją wzroku, na przykład łapiąc ją za rękę czy łokieć, gdy schodzi po schodach lub przechodzi przez wąskie przejście. Oczywiście nie mam tu na myśli sytuacji ekstremalnych, czyli takich, w których występuje jakieś zagrożenie i nie ma czasu, by pytać osobę niepełnosprawną, czy potrzebuje pomocy.

Nie należy również zmieniać lokalizacji przedmiotów osoby z dysfunkcją wzroku, na przykład podnosić jakiś przedmiot, gdy podejrzewamy, że jej upadł. Możliwe jest, że osoba sama go tam położyła, na przykład położyła dyktafon na podłodze. Jest ona wówczas świadoma lokalizacji tych rzeczy. W sytuacji, gdy podejrzewa się, że osobie z dysfunkcją wzroku jakiś przedmiot upadł, należy ją o tym poinformować i zapytać, czy go podać. Z kolei w sytuacji, gdy za zgodą i/lub na prośbę osoby z dysfunkcją wzroku odkłada się gdzieś jakiś przedmiot, na przykład wiesza płaszcz na wieszaku, trzeba daną rzecz osobie niepełnosprawnej także zwrócić (gdyż może ona mieć problem z samodzielnym jej odnalezieniem).

Sugerowałabym nauczycielom akademickim, by pytali studentów o ich potrzeby. Jest to oczywiście możliwe tylko wówczas, gdy nauczyciel akademicki jest świadomy, że dana osoba jest niepełnosprawna. Warto pamiętać, że niektóre niepełnosprawności nie są zauważalne na pierwszy rzut oka, a wtedy zachowanie $\mathrm{z}$ nich wynikające może być interpretowane nie jako konsekwencja niepełnosprawności, ale na przykład jako przejaw nieśmiałości czy nawet braku kultury.

Specyficzną sytuację generuje edukacja zdalna. Zmniejsza ona znacznie prawdopodobieństwo, że nauczyciel akademicki zauważy, że dana osoba jest niepełnosprawna. W takiej sytuacji niezbędne jest, by nauczyciel akademicki został poinformowany o potrzebach wynikających z niepełnosprawności studenta (czy to przez samego studenta, czy przez inne osoby lub jednostki ds. osób niepełnosprawnych funkcjonujące na danej uczelni). Zapytanie przez nauczyciela akademickiego o potrzeby studenta niepełnosprawnego jest dla studenta komunikatem o otwartości i chęci udzielenia pomocy ze strony osoby prowadzącej zajęcia.

Pytając osobę niepełnosprawną o niepełnosprawność i wynikające z niej potrzeby, należy prosić o informacje niezbędne w celu udzielenia adekwatnej do potrzeb pomocy. Odradzałabym wypytywanie o szczegóły, które nie są związane ze studiowaniem. W ten sposób uzyska się potrzebne informacje, nie naruszając prywatności osoby z niepełnosprawnością. Nie należy obawiać się zadawania pytań lub tego, że pytanie sprawi jej przykrość. Radziłabym pytać także, gdy podejrzewa się, że dla danej osoby mówienie na ten temat jest trudne. Po pierwsze, jest to najlepszy sposób na udzielenie właściwej do potrzeb pomocy. Po drugie, częstsze rozmawianie na temat wynikających z niepełnosprawności potrzeb może spowodować, że takie rozmowy staną się dla osoby niepełnosprawnej łatwiejsze (nie będą generowały takiego jak wcześniej stresu, będzie ona potrafiła precyzyjniej komunikować swoje potrzeby). Powtórzę to jeszcze raz, najlepszym źródłem informacji o potrzebach oraz o sposobie, w jaki można pomóc, jest osoba niepełnosprawna. 
W odniesieniu do edukacji zdalnej w przypadku studentów z niepełnosprawnością narządu wzroku w literaturze przedmiotu zalecane jest:

1) niestosowanie w przekazie video określeń takich, jak np.: ,jak widac””; przedstawianie tego, co widać, w postaci opisu słownego;

2) w przypadku pisania na tablicy (np. wzorów) pokazywanie kamerą maksymalnie blisko fragmentu tablicy, na którym w danym momencie powstaje tekst;

3) w przypadku pokazywania w trakcie zajęć online obrazów, schematów, wzorów, pokazywanie na ekranie tylko tych elementów, a nie szerokiego planu obejmującego osobę prowadzącą zajęcia (Hejmanowski i in., b.d.);

4) uwzględnienie, że osoby korzystające z programów udźwiękowiających mogą potrzebować więcej czasu na dotarcie do niektórych treści i/lub wykonanie niektórych czynności;

5) upewnienie się, że osoba, która będzie brała udział w spotkaniu online, zna narzędzie, za pośrednictwem którego odbędzie się spotkanie (Jak zwiększyć dostępność spotkania online?, b.d.);

6) w zadaniach udostępnianych $w$ formie elektronicznej unikanie stosowania rozwiązywania zadania techniką „przeciągnij i upuść” (Wskazówki dotyczące adaptacji materiałów, b.d.);

7) stosowanie precyzyjnego opisu słownego; unikanie określeń takich, jak np.: „tutaj”, zamiast podania dokładnej lokalizacji w przestrzeni;

8) czytanie wyświetlanego tekstu, opisywanie wyświetlanej treści (Zadrożny, b.d.; Wsparcie edukacyjne studentów z niepełnosprawnością wzrokową, b.d.).

Poniżej przedstawiam własne uwagi i sugestie dotyczące dostosowania zajęć zdalnych do potrzeb osób z niepełnosprawnością narządu wzroku.

W trakcie zajęć online należy czytać na głos wpisy pojawiające się na czacie. Osoba słabowidząca/niewidoma może mieć problem ze śledzeniem pojawiających się na czacie informacji. Ponadto czat może być niedostępny dla osób korzystających z programów do odczytu ekranu. Jeśli czat jest dostępny przy użyciu programu do odczytu ekranu, to jednoczesne korzystanie $\mathrm{z}$ niego i słuchanie transmisji video może być niekomfortowe lub nawet niemożliwe. Głosy (wypowiedzi słowne i odczytywane przez program udźwiękowiający treści czatu) mogą się nakładać, wskutek czego może dojść do sytuacji, że żaden z komunikatów nie zostanie przez studenta właściwie zrozumiany albo zrozumie on tylko treść jednego z komunikatów. Jeżeli osoba prowadząca zajęcia zada na głos pytanie, a jakiś student udzieli na nie odpowiedzi na czacie i nauczyciel akademicki skomentuje wpis na czacie na przykład słowami: „Tak, ma Pan/Pani rację, o to właśnie chodzi”, to osoba $\mathrm{z}$ dysfunkcją narządu wzroku może w ogóle nie zorientować się, jak brzmiała udzielona przez studenta poprawna odpowiedź. Dlatego, jeżeli w zajęciach uczestniczy osoba z dysfunkcją narządu wzroku, sugerowałabym poproszenie studentów, by wypowiadali się, korzystając z mikrofonów i nie udzielali odpowiedzi na czacie. Natomiast w sytuacji, gdy pojawią się jakieś wpisy na czacie lub odpowiedzi na pytania, proponuję odczytywanie ich na głos, na przykład: „Pan/Pani [imię] pisze, że...” . 
W powyżej przytoczonych zaleceniach pochodzących z publikacji dotyczących dostępności zajęć online dla osób niepełnosprawnych pojawiło się zalecenie, by możliwie zbliżać kamerą istotne w danym momencie elementy obrazu (np. tekst pisany na tablicy), a nie pokazywać szerokiego planu z salą i osobą prowadzącą zajęcia. Do zalecenia tego dodam ze swojej strony jedną drobną uwagę. Sugerowałabym niedzielenie ekranu na treści udostępniane i np. okienka, w których widać osobę prowadzącą zajęcia i innych studentów. Spowoduje to, że treść, do której odnosi się wypowiedź osoby prowadzącej zajęcia, np. schemat, będzie lepiej widoczna. Takie rozwiązanie nie jest oczywiście możliwe we wszystkich narzędziach wykorzystywanych do pracy zdalnej. Ponadto nie powinno się go stosować w sytuacji, gdy w zajęciach bierze udział osoba z dysfunkcją narządu słuchu, która odczytuje wypowiedź z ruchu warg. Taka osoba musi widzieć twarz osoby prowadzącej zajęcia.

Jeśli w zajęciach uczestniczy zarówno osoba słabowidząca, jak i osoba z niepełnosprawnością narządu słuchu, która odczytuje mowę z ruchu warg, ma miejsce kolizja interesów. Należy wówczas uzgodnić z tymi osobami najlepsze z możliwych rozwiązanie, które sprawi, że zajęcia będą dostępne dla obu tych osób. Może to być na przykład przesłanie studentowi z niepełnosprawnością narządu wzroku materiałów, by wyświetlał je na własnym ekranie. Wówczas w narzędziu do zajęć online będzie można pokazać zarówno omawiany materiał, jak i twarz osoby mówiącej. W mojej pracy magisterskiej pisałam o problemie, jakim jest występowanie rozbieżności pomiędzy omawianym $\mathrm{w}$ danym momencie materiałem (stroną/slajdem wyświetlanym przez osobę prowadzącą zajęcia na rzutniku) a treściami, na jakie patrzy w danym momencie student słabowidzący (chodzi o sytuację, w której student słabowidzący nie jest w stanie zapoznać się z treścią wyświetlaną na rzutniku, ale może się z nią zapoznać w trakcie zajęć, np. przy użyciu własnego komputera). Sugerowałam wówczas, by słownie informować o tym, który slajd/ stronę w danym momencie się wyświetla (Migacz, 2020). Z tego rozwiązania należałoby skorzystać również w omawianej w tym akapicie sytuacji.

W pracy magisterskiej opisywałam przykład wspólnego/jednoczesnego wykonywania czynności na komputerze przez osobę prowadzącą zajęcia i studentów. Sugerowałam wówczas, by zwracać uwagę, czy student z niepełnosprawnością jest na tym samym etapie wykonywanych czynności, co osoba prowadząca zajęcia. Chodzi o uniknięcie sytuacji, w której trzeba będzie ponownie tłumaczyć studentowi wykonywane czynności - gdyż w odróżnieniu od reszty grupy nie jest on w stanie replikować ich z opóźnieniem (Migacz, 2020).

W przypadku edukacji zdalnej nie ma możliwości obserwowania, czy student niepełnosprawny jest na tym samym etapie wykonywania czynności, co osoba prowadząca zajęcia. Taką informację można jedynie uzyskać od studenta. Jednak dla studenta może być niekomfortowe proszenie, by na niego zaczekano. Jeśli osoba prowadząca zajęcia nie będzie precyzyjnie opisywała wykonywanych czynności (takie opisywanie wykonywanych czynności jest zalecane w sytuacji, gdy w zajęciach bierze udział osoba z niepełnosprawnością narządu wzroku), wówczas osoba niewidoma (i część osób słabowidzących) nie będzie w stanie w ogóle replikować wykonywanych przez nauczyciela akademickiego czynności. Natomiast pozostała część osób słabowidzących będzie w stanie replikować 
te czynności, ale tylko śledząc stale ekran. Wymagałoby to jednak albo dzielenia ekranu pomiędzy okno z narzędziem do zajęć online i okno programu, w którym wykonywane są czynności, albo korzystanie z dwóch ekranów (ewentualnie dwóch urządzeń). $\mathrm{Na}$ podstawie tego przykładu jasno widać, jak ważne jest, by precyzyjnie opisywać słownie wykonywane czynności.

Pewnym rozwiązaniem w sytuacji, gdy osoba prowadząca zajęcia precyzyjnie słownie opisuje wykonywane czynności, ale student nie jest w stanie wykonywać ich w takim samym tempie, jak reszta grupy, jest nagranie. Wówczas student będzie mógł odtworzyć przebieg zajęć w dowolnym czasie, we własnym tempie. Jeśli jednak osoba prowadząca zajęcia nie będzie dokładnie słownie opisywała czynności, wówczas rozwiązanie takie sprawdzi się tylko w przypadku części osób słabowidzących, mianowicie tych, które będą w stanie odtworzyć wykonywane czynności nie tylko na podstawie nagranych komunikatów werbalnych, ale także na podstawie obrazu (nagrania video), natomiast nie sprawdzi się w przypadku osób niewidomych i części osób słabowidzących. Rozwiązanie, jakim jest replikowanie wykonywanych czynności na podstawie nagrania, ma też taką wadę, że w razie pojawienia się problemów, wątpliwości, student nie może w danym momencie skierować do osoby prowadzącej prośby o wyjaśnienie niejasnych kwestii.

Z powyższych rozważań wynika, że nagrywanie zajęć jest pewnym rozwiązaniem, ale najlepiej byłoby, gdyby student replikował wykonywane czynności podczas zajęć. W tym celu ważne jest zapewnienie dobrej atmosfery, aby student - dzięki otwartej postawie osoby prowadzącej zajęcia - nie czuł dyskomfortu w sytuacji, gdy chce poprosić, by zaczekano na niego z kolejnym etapem wykonywanych czynności lub gdy osoba prowadząca zajęcia pyta studentów, czy skończyli już daną czynność, a student niepełnosprawny musi udzielić odpowiedzi przeczącej (jest jedyną osobą, która nie zakończyła konkretnej czynności).

Oczywiście rozumiem, że w trakcie zajęć powinno się zrealizować w pełni przewidziany programem materiał oraz że czas zajęć jest ograniczony. W związku z tym w sytuacji, gdy opóźnienia spowodowane czekaniem, by student niepełnosprawny równocześnie $z$ resztą grupy rozpoczynał dany etap działania, okażą się zbyt duże, radziłabym znalezienie innego rozwiązania tego problemu. Może to być opisane powyżej nagrywanie zajęć i replikowanie wykonywanych $\mathrm{w}$ ich trakcie czynności przez studenta niepełnosprawnego w innym czasie. Warto byłoby wówczas zaproponować studentowi, by w przypadku pojawienia się jakichkolwiek problemów czy wątpliwości skontaktował się z osobą prowadzącą zajęcia, np. mailowo lub w trakcie indywidualnej konwersacji video (będzie wtedy możliwe udostępnienie osobie prowadzącej własnego ekranu, tak by widziała ona dokładnie, na czym polega problem).

Jeżeli w trakcie zajęć nauczyciel akademicki udostępnia swój ekran, sugerowałabym powiększenie jego treści. Można to zrobić, korzystając z ustawień systemowych - skalowania. Zmiana taka będzie użyteczna dla części osób słabowidzących. W sytuacji udostępniania ekranu, np. korzystania $\mathrm{z}$ jakiegoś programu komputerowego przy normalnych ustawieniach ekranu, może bowiem dojść do sytuacji, w której student słabowidzący nie będzie widział, jakie opcje w programie wybiera osoba prowadząca zajęcia. Może on na przykład widzieć, że nauczyciel akademicki wybrał opcję czwartą z listy, 
jednak nie będzie w stanie odczytać, jaka jest to opcja. Oczywiście tutaj znowu wraca kwestia dokładnego słownego opisywania wykonywanych czynności.

Myślę, że dostosowując zajęcia do potrzeb osoby niepełnosprawnej, warto wziąć pod uwagę zarówno jej specyficzne potrzeby, jak i komfort obu stron - zarówno studenta niepełnosprawnego, jak i nauczyciela akademickiego. Słowne opisywanie wykonywanych czynności może niekiedy wymagać znacznej zmiany dotychczasowych nawyków związanych ze sposobem prowadzenia zajęć. Jednak w większości przypadków drastyczna zmiana nawyków nie będzie konieczna, wystarczające może się okazać powiększenie treści własnego ekranu, aby student słabowidzący mógł śledzić czynności wykonywane przez osobę prowadzącą zajęcia. Taki sposób dostosowania zajęć wymaga jednak precyzyjnej wiedzy na temat potrzeb studenta.

Pozostając przy przykładzie wspólnego wykonywania czynności w programie komputerowym, warto zwrócić uwagę na różne drobne rzeczy, które mogą być pomocne dla studenta $\mathrm{z}$ dysfunkcją wzroku. Pisałam już, że nie należy używać określeń nieprecyzyjnych, na przykład mówić: „uruchamiam tę opcję”. W tym miejscu dodam jeszcze, że przy formułowaniu precyzyjnych słownych komunikatów można skorzystać z informacji, z których część osób pełnosprawnych na co dzień nie korzysta. Można na przykład podać, jaki jest skrót klawiszowy do danej opcji. Można podać, jaka jest ścieżka dostępu przy użyciu klawiatury, np. że dana opcja znajduje się po wejściu na pasek menu pod literą A. W konsolach, programach do pisania kodu w języku programowania, można wykorzystać numerację wierszy - powiedzieć, w którym wierszu znajduje się polecenie obecnie omawiane albo którego należy w danym momencie użyć (oczywiście odczytując również treść tego polecenia).

W przytaczanych powyżej zaleceniach pojawia się pokazywanie w jak największym zbliżeniu treści pisanych na tablicy. Jeśli chodzi o osoby z niepełnosprawnością wzroku, odradzałabym w ogóle pisanie treści na tablicy i pokazywanie ich przy użyciu kamery. Taki obraz jest niedostępny dla czytników ekranu. Oznacza to, że osoby niewidome, nawet jeśli nagrają zajęcia, nie będą mogły później samodzielnie zapoznać się z napisaną na tablicy treścią. Sugerowałabym pisanie, a także rysowanie, przy użyciu odpowiednich programów komputerowych. W trakcie zajęć prowadzący może wtedy udostępniać swój ekran. Natomiast napisane na komputerze treści należałoby udostępnić studentowi niepełnosprawnemu (jeżeli nie chce się ich udostępniać wszystkim studentom, z zastrzeżeniem, że nie wyraża się zgody na rozpowszechnianie przekazanych treści). Przygotowanie treści, które w przypadku zajęć konwencjonalnych pisałoby się na tablicy, w postaci elektronicznej, ma też tę zaletę, że można je wielokrotnie wykorzystać. Zaproponowane rozwiązanie warto byłoby również rozważyć $\mathrm{w}$ przypadku zajęć konwencjonalnych. W trakcie takich zajęć osoby z dysfunkcją narządu wzroku mogą nie być w stanie odczytywać treści zapisywanych na tablicy, robić na ich podstawie notatek, wówczas wersja elektroniczna byłaby również dobrym rozwiązaniem zapewniającym im pełny dostęp do przekazywanych treści.

Udostępniając swój ekran, należy pamiętać, by nie udostępniać treści w postaci niezbliżonej. Na przykład nie pokazywać całej strony A4, lecz zbliżenie tego fragmentu strony, do którego w danym momencie odnosi się osoba prowadząca zajęcia. Nie chodzi mi tutaj o zbliżanie poszczególnych elementów na slajdzie. Zakładam bowiem, że na slaj- 
dach jest dość duża czcionka, by tekst był czytelny przy wyświetlaniu ich na rzutniku. Spotkałam się jednak z sytuacją, kiedy osoba prowadząca spotkanie wyświetlała na ekranie całą stronę A4, na której był tekst sformatowany jak standardowy plik tekstowy, czyli czcionką 12 pkt. Taki sposób wyświetlania treści sprawia, że są one niedostępne dla osób słabowidzących, które mogłyby skorzystać z wyświetlanych treści, gdyby miały one odpowiednie parametry (były sformatowane w większej czcionce albo na ekranie pokazano by ich zbliżenie).

Sugerowałabym, aby korzystając z narzędzi do edukacji zdalnej, umieszczać konkretne treści zawsze w tym samym miejscu, np. zawsze rozpoczynać zajęcia zdalne na głównym panelu grupy w MS Teams, a zadania umieszczać zawsze w zakładce „Zadania”. Ułatwi to osobom z dysfunkcją narządu wzroku orientowanie się w przekazywanych treściach.

W przytoczonych powyżej zaleceniach pochodzących ze strony Działu ds. Osób Niepełnosprawnych Uniwersytetu Jagiellońskiego była mowa, aby upewnić się, czy student zna narzędzie, za pośrednictwem którego odbędzie się spotkanie online. Ze swojej strony dodam do tego zalecenia sugestię: przed pierwszymi zajęciami można przesłać studentom krótką instrukcję korzystania $\mathrm{z}$ danego narzędzia. W przypadku osób słabowidzących przydatne będzie podanie informacji o lokalizacji opcji danego narzędzia, np.: gdzie trzeba kliknąć, aby dołączyć do spotkania albo aby włączyć/wyłączyć mikrofon. W przypadku osób korzystających z programu udźwiękowiającego warto byłoby sprawdzić, czy narzędzie do komunikacji online, $\mathrm{z}$ jakiego zamierza się skorzystać $\mathrm{w}$ trakcie danego kursu, będzie dla nich dostępne. Można przetestować korzystanie $\mathrm{z}$ danego narzędzia przy użyciu programu udźwiękowiającego. Popularnym (wykorzystywanym zarówno do celów prywatnych, jak i w pracy) i bezpłatnym programem do odczytu zawartości ekranu jest NVDA. Oprócz upewnienia się, czy student zna dane narzędzie, sprawdzenia, czy jest ono dostępne dla użytkowników programów udźwiękowiających, radziłabym korzystanie $\mathrm{w}$ trakcie danego kursu, a jeśli to możliwe, $\mathrm{w}$ trakcie wszystkich zajęć $\mathrm{w}$ ramach danego toku studiów, z jednego narzędzia do prowadzenia zajęć online. Nie chodzi o to, by zupełnie zrezygnować z innych form komunikacji elektronicznej i przenieść wszystko na przykład na platformę MS Teams, ale o to, by starać się unikać korzystania z wielu różnych (a co za tym idzie o różnym interfejsie i różnym poziomie dostępności) narzędzi do konferencji online (prowadzenia zajęć zdalnych w czasie rzeczywistym). Korzystanie na różnych kursach $\mathrm{z}$ różnych komunikatorów nie sprawi, że studia będą dla studenta $\mathrm{z}$ niepełnosprawnością wzrokową niedostępne, jednak korzystanie z jednego narzędzia do komunikacji online sprawi, że studiowanie będzie dla niego bardziej komfortowe. Zmniejszy to także prawdopodobieństwo przeoczenia przez niego treści przekazanych przez osobę prowadzącą zajęcia.

Sugerowałabym, by harmonogram zajęć przewidywał przerwy pomiędzy spotkaniami online (np. 5-minutowe). Osoby z niepełnosprawnością narządu wzroku mogą bowiem potrzebować więcej czasu, zarówno na dotarcie do pewnych treści, jak i na samo przełączenie się pomiędzy konwersacjami.

W odniesieniu do narzędzi wykorzystywanych do spotkań online dodam jeszcze jedną uwagę. Ma ona charakter ogólny - tzn. ma zastosowanie dla wszystkich uczestników zajęć, nie tylko dla osób z niepełnosprawnością narządu wzroku. Przy udostępnianiu 
ekranu i materiałów na ekranie radziłabym zwrócić uwagę, by wyświetlane treści nie były zasłaniane przez okienko z widokiem osoby prowadzącej zajęcia i okienka innych osób.

W materiałach dotyczących dostępności spotkania online dla osób z niepełnosprawnością narządu wzroku znalazłam szereg rad dotyczących adaptacji udostępnianych materiałów. Sądzę, że pojawiły się one tam, ponieważ edukacja zdalna spopularyzowała korzystanie z materiałów w formie elektronicznej. Zagadnienie adaptacji materiałów do potrzeb osób z niepełnosprawnością narządu wzroku jest rozległym tematem, dlatego nie będę tutaj omawiać tej kwestii.

Na koniec części poświęconej osobom z niepełnosprawnością wzroku i ich uczestnictwu w edukacji zdalnej, chciałabym wspomnieć o kilku pozytywnych konsekwencjach tej edukacji. Po pierwsze, w przypadku niektórych osób słabowidzących edukacja zdalna zlikwidowała problem polegający na tym, że student niepełnosprawny nie orientował się, do jakiej części materiału (slajdu, strony) odnosi się w danym momencie osoba mówiąca. Po drugie, w przypadku komunikacji online większość uczestników nie widzi się nawzajem. Nie występuje więc problem pozornego kontaktu wzrokowego. Zniknął też problem związany z nawiązywaniem komunikacji z osobą z niepełnosprawnością narządu wzroku. W trakcie spotkania online osoba prowadząca zajęcia musi zwracać się do wszystkich osób w uzgodniony z daną grupą studentów sposób, np. Pan/Pani + imię, więc nawiązuje komunikację ze studentem $\mathrm{z}$ niepełnosprawnością wzrokową $\mathrm{w}$ taki sam sposób, jak z innymi studentami.

\section{OSOBY Z NIEPEŁNOSPRAWNOŚCIĄ NARZĄDU SŁUCHU}

W przypadku edukacji zdalnej studentów z niepełnosprawnością narządu słuchu zalecane jest:

1) przy korzystaniu z komunikatorów video unikanie stania/siedzenia tyłem do źródła światła;

2) branie pod uwagę, że student w trakcie zajęć online może używać transkrypcji na żywo (np. przy użyciu LiveTranscribe, Google Assistant Speech-To-Text albo SpeechTexter), kładąc telefon/tablet blisko głośnika;

3) uwzględnienie, że transkrypcja na żywo jest nieco wolniejsza niż zwykły strumień mowy, dlatego czasami student może na pytania odpowiadać z opóźnieniem, dlatego należy odczekać, by student mógł zrozumieć zarówno kontekst pytania, jak i samo pytanie;

4) upewnianie się, że osoba $z$ dysfunkcją narządu słuchu zrozumiała wypowiedź (jeżeli korzysta ona z transkrypcji na żywo, to program może od czasu do czasu przekręcać słowa);

5) zadbanie, by tylko jedna osoba mówiła w danym czasie, aby głosy się nie nakładały i jakość dźwięku była dobra;

6) zadbanie, by tylko osoba mówiąca w danym czasie miała włączony mikrofon, poproszenie uczestników spotkania, by wyciszyli swoje mikrofony i włączali je tylko wtedy, gdy chcą zabrać głos w dyskusji - umożliwi to zredukowanie do minimum zbędnych odgłosów z otoczenia i uniknięcie pogłosu; 
7) korzystanie ze sprzętu dobrej jakości, by zapewnić dobrą jakość dźwięku;

8) w trakcie mówienia kierowanie twarzy w stronę kamery, tak aby osoba $z$ dysfunkcją narządu słuchu mogła w miarę możliwości odczytywać wypowiedź z ruchu warg;

9) umożliwienie zadawania pytań, np. w komentarzach, co pozwoli osobie z dysfunkcją narządu słuchu na śledzenie dyskusji;

10) jeśli w zajęciach uczestniczy osoba, która potrzebuje pomocy tłumacza języka migowego, nagrywanie zajęć i przesyłanie nagrań tłumaczowi (Hejmanowski i in., b.d.);

11) zadbanie o odpowiednie oświetlenie (powinno być równomierne i niezbyt jasne), upewnienie się, że twarz osoby prowadzącej zajęcia będzie dobrze widoczna i nic nie będzie rzucało na nią cienia;

12) zadbanie o zminimalizowanie hałasu dobiegającego $\mathrm{z}$ otoczenia (zamknięcie drzwi, okna);

13) jeśli narzędzie, za pośrednictwem którego odbywa się spotkanie online, umożliwia generowanie napisów w czasie rzeczywistym, skorzystanie z tej opcji (Jak zwiększyć dostępność spotkania online?, b.d.).

W przypadku osób z niepełnosprawnością słuchową w trakcie zajęć zdalnych użytecznym narzędziem komunikacji może być czat. Korzystanie z czatu pozwoli osobie słabosłyszącej/niesłyszącej na śledzenie dyskusji i uczestnictwo w niej. Jest to dobre rozwiązanie, zwłaszcza gdy osoby biorące udział w zajęciach nie włączają kamery podczas wypowiadania się. Wówczas osoba odczytująca mowę z ruchu warg nie może zrozumieć przekazu osoby, która mówi, ale nie pokazuje swojej twarzy (podobnie ma się rzecz w sytuacji, gdy osoba mówiąca ma włączoną kamerę, ale jej twarz jest źle oświetlona lub coś ją zasłania, lub kamera nie jest skierowana na twarz osoby mówiącej). Przy użyciu czatu można także zadawać pytania osobie z niepełnosprawnością słuchową. Wtedy osoba prowadząca zajęcia będzie miała pewność, że student zrozumiał treść pytania.

Pisałam o tym w przypadku osób z niepełnosprawnością wzrokową, tutaj tylko krótko przypomnę. Gdy w zajęciach uczestniczy osoba odczytująca mowę z ruchu warg, osoba prowadząca zajęcia powinna być widoczna na ekranie w każdym momencie, w jakim się wypowiada. Powinno unikać się sytuacji, gdy na ekranie widać jedynie udostępnianą treść, nie widać natomiast twarzy osoby mówiącej.

Ważne jest także zadbanie o stabilność łącza. O ile w przypadku przerywania głosu osoby pełnosprawne najczęściej mogą z łatwością domyślić się treści przekazu, o tyle dla osób słabosłyszących może to być niemożliwe. Zacinanie się obrazu może uniemożliwiać odczytywanie wypowiedzi z ruchu warg. Przy czym należy zaznaczyć, że problem z łączem może wystąpić u każdej z osób biorących udział w spotkaniu online. To, że osoba prowadząca zajęcia ma dobrą jakość obrazu i dźwięku, nie oznacza, że wszystkie pozostałe osoby dobrze ją słyszą i że obraz się nie zawiesza. Dlatego radziłabym nagrywanie zajęć przez osobę prowadzącą (bezpośrednio u niej na komputerze). W przypadku pojawienia się zakłóceń w przekazie nauczyciel akademicki będzie mógł przekazać studentowi z niepełnosprawnością słuchu nagranie dobrej jakości. Oczywiście można przyjąć zasadę, że nauczyciel akademicki nagrywa i udostępnia osobie z dysfunkcją narządu słuchu wszystkie zajęcia. Takie rozwiązanie zlikwiduje potrzebę każdorazowego proszenia o nagranie w sytuacji, gdy pojawi się problem z łączem. 


\section{OSOBY Z NIEPEŁNOSPRAWNOŚCIĄ NARZĄDU MOWY}

Nie znalazłam szczególnych zaleceń dotyczących pracy ze studentami z niepełnosprawnością narządu mowy, które odnosiłyby się tylko do edukacji zdalnej. W przypadku tych osób zdalne zajęcia mogą utrudniać komunikację. Zrozumienie osoby z problemami z mową, mówiącej do mikrofonu, może być znacznie trudniejsze niż zrozumienie jej wypowiedzi w trakcie kontaktu bezpośredniego. Niezależnie od tego należy starać się zrozumieć wypowiedzi studenta, traktować niepłynność wypowiedzi jako normalną, nie dopowiadać fraz, cierpliwie czekać, aż student skończy swoją wypowiedź (Inne niepełnosprawności, b.d.; Wójtowicz, b.d.).

Jeżeli student z problemami w mówieniu będzie preferował taką formę, może on komunikować się przy użyciu czatu. Uważam jednak, że decyzję o korzystaniu z takiej formy komunikacji powinien podjąć student. Jeśli wypowiedź osoby z problemami w mówieniu jest niezrozumiała, należy poprosić o jej powtórzenie. Uważam, że w sytuacji, gdy mimo powtórzenia wypowiedź nadal nie jest w pełni zrozumiała, można poprosić o napisanie jej na czacie.

\section{OSOBY Z NIEPEŁNOSPRAWNOŚCIĄ NARZĄDU RUCHU}

W odniesieniu do edukacji zdalnej zalecane jest uwzględnienie, że osoba z niepełnosprawnością narządu ruchu może potrzebować więcej czasu na dotarcie do niektórych treści czy wykonanie niektórych czynności (Jak zwiększyć dostępność spotkania online?, b.d.).

Podobnie jak w przypadku osób z niepełnosprawnością narządu wzroku, sugerowałabym uwzględnienie w harmonogramie zajęć krótkich przerw między spotkaniami online. Umożliwi to osobie z niepełnosprawnością rąk na spokojne przełączenie się między zajęciami.

Edukacja zdalna może pozytywnie wpływać na możliwość uczestnictwa w zajęciach osób z niepełnosprawnością ruchową. Znika bowiem kwestia dotarcia na zajęcia i problem niedostosowanych pomieszczeń. Nie chciałabym zostać źle zrozumiana, dlatego dodam, że nie uważam, by dobrym rozwiązaniem było w przypadku osób z niepełnosprawnością ruchową stosowanie wyłącznie edukacji zdalnej (zamienienie edukacji konwencjonalnej na zdalną w przypadku, gdy osoby pełnosprawne uczestniczą w zajęciach konwencjonalnych). Dostosowania edukacji do potrzeb osób z niepełnosprawnością ruchową powinny zmierzać w kierunku umożliwienia uczestniczenia im w zajęciach - nie chodzi o to, aby zagwarantować, by osoby niepełnosprawne nie musiały wychodzić z domu, lecz wręcz przeciwnie, by miały możliwość wyjścia.

W przypadku edukacji zdalnej znika też kwestia wykonywania w trakcie zajęć czynności wymagających podnoszenia rąk, takich jak zgłaszanie się. W przypadku edukacji zdalnej zgłaszanie chęci odpowiedzi następuje zazwyczaj przez naciśniecie odpowiedniego przycisku. Nie ma tutaj znaczenia, w jaki sposób zostanie dokonana ta czynność - czy osoba $\mathrm{z}$ niepełnosprawnością ruchową korzysta z komputera przy użyciu rąk, nóg, ust czy ruchu gałek ocznych. 


\section{ZAKOŃCZENIE}

Przedstawiłam wybrane adaptacje procesu studiowania adresowane do wybranych grup osób z niepełnosprawnościami oraz szereg informacji ogólnych, w tym informacje dotyczące komunikacji z osobami niepełnosprawnymi. Informacje te mogą być użyteczne zarówno dla nauczycieli akademickich, jak i dla innych osób.

W przypadku niektórych adaptacji edukacji zdalnej może dojść do kolizji interesów. Dla części osób słabowidzących korzystne byłoby, aby na ekranie widoczne były tylko omawiane w danym momencie treści. Nie potrzebują one widzieć twarzy osoby prowadzącej zajęcia. Natomiast w przypadku osób odczytujących mowę z ruchu warg konieczne jest, aby twarz osoby mówiącej była widoczna podczas całych zajęć (uszczegóławiając: w każdym momencie, w którym osoba ta się wypowiada). Dla osób z niepełnosprawnością narządu wzroku korzystanie z czatu może być znacznym utrudnieniem, dlatego ważne jest, aby osoba prowadząca zajęcia odczytywała treści pojawiające się na czacie. Natomiast w przypadku osób z niepełnosprawnością narządu słuchu czat może być bardzo użytecznym narzędziem. Zalecałabym jego stosowanie, zwłaszcza gdy osoby wypowiadające się nie włączają kamery w trakcie wypowiedzi lub nie jest możliwe odczytywanie ich wypowiedzi z ruchu warg. Osoba prowadząca zajęcia może komunikować się pisemnie z osobą z niepełnosprawnością słuchową. Wykorzystanie czatu może być także użyteczne w przypadku osób z niepełnosprawnością narządu mowy.

Jak już pisałam, oraz jak wynika z opisanej powyżej kolizji interesów, kluczowe dla udzielenia właściwej do potrzeb pomocy jest poznanie potrzeb studenta niepełnosprawnego. Dlatego zachęcam studentów niepełnosprawnych, by otwarcie mówili o wynikających z niepełnosprawności potrzebach, by sugerowali możliwe do zastosowania rozwiązania, by mówili, jakich form pomocy, adaptacji zajęć, materiałów, zaliczeń potrzebują. Zachęcam również nauczycieli akademickich, by pytali studentów o ich potrzeby.

Treści zawarte $\mathrm{w}$ tym artykule, $\mathrm{z}$ mojej perspektywy osoby niepełnosprawnej wydają się dość oczywiste. Wiem jednak, że zastosowanie opisanych zaleceń może wymagać koncentracji i przełamania dotychczasowych nawyków w prowadzeniu zajęć. Osoba prowadząca może sprawdzić, czy prowadzone przez nią zajęcia są w pełni dostępne dla osób z niepełnosprawnością narządu wzroku. Najprostszym sposobem jest nagranie zajęć, a następnie odsłuchanie samego dźwięku i sprawdzenie, czy przekaz audio jest zrozumiały, czy zawiera wszystkie przekazywane w trakcie zajęć treści (w takim stopniu, w jakim jest to możliwe). Podobnie można sprawdzić, czy zajęcia są dostępne dla osób z niepełnosprawnością słuchową. Należy wówczas odtworzyć sam obraz, upewnić się, czy wszystkie wyświetlane treści są dobrze widoczne oraz czy twarz osoby mówiącej jest widoczna w sposób umożliwiający odczytywanie treści wypowiedzi z ruchu warg (w tym, czy jest ona widoczna na ekranie w każdym momencie, w którym wypowiada się). Myślę, że takie ćwiczenie może również pomóc w zrozumieniu sytuacji osób niepełnosprawnych i uwrażliwić na ich problemy. 


\section{BIBLIOGRAFIA}

DARe-Learning (b.d.). http://www.darelearning.eu/pl.inne_niepelnosprawnosci.html

Dostosowanie procesu kształcenia (b.d.). Dział ds. Osób Niepełnosprawnych Uniwersytet Jagielloński w Krakowie. https://don.uj.edu.pl/dla-studentow/rodzaj-trudnosci/wzrok/ dostosowanie-procesu-ksztalcenia

Hejmanowski, S., Lubawy, H., Pyryt, K., Rutz, A., Skoczyńska, M., Zakrzewski, B., (b.d.). Kilka zasad dostępnego e-learningu. https://amu.edu.pl/_data/assets/pdf_ file/0034/168919/Kilka-zasad-dostepnego-e-learningu-UAM-.pdf

Jak zwiększyć dostępność spotkania online? (b.d.). Dział ds. Osób Niepełnosprawnych Uniwersytet Jagielloński w Krakowie. https://don.uj.edu.pl/dla-pracownikow/jak-zwiekszyc-dostepnosc-spotkania-online

Migacz, J. (2020). Relacje pomiędzy nauczycielami akademickimi a studentami niepełnosprawnymi z perspektywy nauczycieli akademickich. https://www.ap.uj.edu.pl/diplomas/ attachments/file/download/122770/

Szczepankowski, B. (b.d.). Wskazówki dla osób prowadzacych zajęcia dydaktyczne ze studentami niesłyszącymi i słabosłyszącymi. Fundacja Instytut Rozwoju Regionalnego. https:// firr.org.pl/wp-content/uploads/2018/04/Wskazowki_dla_wykladowcow_sluch.pdf

Ustawa z dnia 4 lutego 1994 r. o prawie autorskim i prawach pokrewnych, Dz. U. 1994 Nr 24 poz. 83.

Wójtowicz, A. (b.d.), Wskazówki dla osób prowadzących zajęcia dydaktyczne ze studentami $z$ niepetnosprawnościa mowy. Fundacja Instytut Rozwoju Regionalnego. https://firr.org. pl/wp-content/uploads/2018/04/Wskazowki_dla_wykladowcow_mowa.pdf

Wskazówki dotyczące adaptacji materiałów (b.d). Dział ds. Osób Niepełnosprawnych Uniwersytet Jagielloński w Krakowie. https://don.uj.edu.pl/dla-pracownikow/wskazowki-dotyczace-adaptacji-materialow

Wsparcie edukacyjne studentów z niepełnosprawnością ruchową (b.d.). http://www.darelearning.eu/pl.niepelnosprawnosc_ruchowa.html, DARe-Learning

Wsparcie edukacyjne studentów z niepełnosprawnością słuchową (b.d.). http://www.darelearning.eu/pl.niepelnosprawnosc_sluchowa.html, DARe-Learning

Wsparcie edukacyjne studentów z niepełnosprawnością wzrokową (b.d.). http://www.darelearning.eu/pl.niepelnosprawnosc_wzrokowa.html, DARe-Learning

Zadrożny, J. (b.d.), Wskazówki dla osób prowadzących zajęcia dydaktyczne ze studentami niewidomymi i słabowidzacymi. Fundacja Instytut Rozwoju Regionalnego. https://firr.org.pl/ wp-content/uploads/2018/04/Wskazowki_dla_wykladowcow_wzrok.pdf 